\title{
COMPARISON OF THE LEVEL OF NUTRITIONAL KNOWLEDGE AND SELECTED BEHAVIOUR AMONG CONSUMERS WITH REGULAR BMI AND THE OBESE
}

\author{
PORÓWNANIE POZIOMU WIEDZY ŻYWIENIOWEJ I WYBRANYCH \\ ZACHOWAŃ U KONSUMENTÓW NORMOWAGOWYCH I OTYŁYCH
}

\begin{abstract}
Summary
Background. Due to the growing obesity epidemic, it is necessary to take action to halt its development. To try to make the desired changes in the diet of obese people, it is necessary to discover their eating habits and what they know about nutrients and their role.

Material and methods. Knowledge and selected nutritional behaviors of people with elevated $(\mathrm{n}=100)$ and normal BMI $(\mathrm{n}=100)$ from Wielkopolska were studied using a direct survey. The aim of the study was to compare some behaviors related to diet and the level of knowledge of people with elevated and normal body mass index.

Results. $59 \%$ of the obese group and $44 \%$ of the reference group never eat breakfast. Dinner was the main meal of the day for $64 \%$ of obese respondents and $68 \%$ of control group. More than half of the respondents ( $63 \%$ obese and $66 \%$ of the reference group) claimed that every day or several times a week they eat 4-5 meals. Obese respondents showed profound knowledge of dietary fiber and natural sources of antioxidants in food. It has been calculated that both groups showed overall average knowledge of food ingredients.

Conclusions. Effective nutritional education is an element necessary to stop the obesity epidemic. It should consist not only in raising the awareness of nutrition, but also in motivating to change current improper habits.
\end{abstract}

Key words: nutritional knowledge, nutritional behaviors, obesity, questionnaire survey 
Jędrusek-Golińska, A., Szymandera-Buszka, K., Magott, M. (2016). Comparison of the level of nutritional knowledge and selected behaviour among consumers with regular BMI and the obese. Nauka Przyr. Technol., 10, 4, \#57. DOI: http://dx.doi.org/10.17306/J.NPT.2016.4.57

\section{Introduction}

Adherence to the principles of good nutrition allows the proper functioning and development of the human body. Both prolonged deficiencies of individual components and their excess intake are dangerous. One of the consequences of improperly balanced energy in the diet is obesity, now considered as an epidemic disease. Statistics show that most people in the world live in countries where overweight and obesity kills more people than underweight. The consequences of obesity are serious. They include an increased risk of many noncommunicable diseases, including cardiovascular disease, cancer and diabetes, as well as physical disability or psychological problems (WHO, 2015). Obesity should be treated, but now more and more importance is given to the development of prevention programs, methods or campaigns. It seems that for the effectiveness of these measures it is necessary to examine eating behaviors and knowledge of obese people in order to offer them personalized changes and consistently support them in changing their eating habits.

The aim of the study was to compare some behaviors related to diet and the level of knowledge of people with increased and normal body mass index.

\section{Material and methods}

The study of a qualitative nature was preceded by a pilot group of 15 people, and carried out from September 2012 to April 2013 in the Wielkopolska region. 200 people took part in the study, 100 with excess weight $(\mathrm{BMI}>30)$ and 100 with normal body mass index (reference group). Direct interview was selected as a research method. The research tool was a closed-questions questionnaire. Respondents were recruited by a physician from a family clinic. Detailed characteristic of the respondents is given in Table 1 . The results are presented as percentage of individual responses, and in order to determine statistical significance of the relationship between the variables, chi-square test was applied ( $p$ value is given) using the Excel spreadsheet and STATISTICA $10(\alpha=0.05)$.

To assess the level of nutritional knowledge, the surveyed were presented with 19 claims. The task of the respondents was to select whether they are true or false. The respondents also had the opportunity to select the answer "I do not know". Questions of a slightly higher level of difficulty were chosen deliberately, in order to test the knowledge of not only well-known principles, but also those requiring the respondents' interest in matters of nutrition. Food ingredients which are considered as elements of a healthy diet were selected for the research. The first group of questions concerned fiber and its effect on the body, the second - the role of calcium in the body and products that may be its source in the diet. Other questions concerned the n-3 and n- 6 fatty acids, probiotics and other bioactive substances. In order to assess the level of knowledge of the components present in food, the frequency of correct answers was calculated as a quotient of the sum of correct responses to the questions listed in the questionnaire and the maximum number of correct answers. The following levels of nutritional knowledge were accepted: low (0.00-0.40), medium (0.41-0.7) and high (0.71-1.00). "I do not know" answers were classified as incorrect. The level of knowledge was compared using t-test $(\alpha=0.05)$. 
Jędrusek-Golińska, A., Szymandera-Buszka, K., Magott, M. (2016). Comparison of the level of nutritional knowledge and selected behaviour among consumers with regular BMI and the obese. Nauka Przyr. Technol., 10, 4, \#57. DOI: http://dx.doi.org/10.17306/J.NPT.2016.4.57

Table 1. Characteristics of respondents

Tabela 1. Charakterystyka respondentów

\begin{tabular}{|c|c|c|c|}
\hline \multicolumn{2}{|c|}{ Feature - Cecha } & \multirow{2}{*}{$\begin{array}{c}\mathrm{OG}^{*}(\%) \\
\mathrm{GO}^{*}(\%)\end{array}$} & \multirow{2}{*}{$\begin{array}{c}\mathrm{RG}^{* *}(\%) \\
\mathrm{GK}^{* *}(\%)\end{array}$} \\
\hline \begin{tabular}{|l} 
Sex \\
Płeć
\end{tabular} & $\begin{array}{l}\text { Women } \\
\text { Kobiety }\end{array}$ & & \\
\hline & $\begin{array}{l}\text { Men } \\
\text { Mężczyźni }\end{array}$ & 45 & 49 \\
\hline \multirow{4}{*}{$\begin{array}{l}\text { Age (years) } \\
\text { Wiek (lata) }\end{array}$} & $<18$ & 9 & 8 \\
\hline & $18-45$ & 40 & 34 \\
\hline & $46-60$ & 29 & 36 \\
\hline & $>60$ & 22 & 22 \\
\hline \multirow[t]{4}{*}{ BMI $\left(\mathrm{kg} / \mathrm{m}^{2}\right)$} & $18.5-24.99$ & - & 100 \\
\hline & $30-34.99$ & 89 & - \\
\hline & $35-39.99$ & 9 & - \\
\hline & $>40$ & 2 & - \\
\hline \multirow[t]{4}{*}{$\begin{array}{l}\text { Education } \\
\text { Wykształcenie }\end{array}$} & $\begin{array}{l}\text { Primary } \\
\text { Podstawowe }\end{array}$ & 13 & 18 \\
\hline & $\begin{array}{l}\text { Vocational } \\
\text { Zawodowe }\end{array}$ & 21 & 20 \\
\hline & $\begin{array}{l}\text { Secondary } \\
\text { Srednie }\end{array}$ & 37 & 38 \\
\hline & $\begin{array}{l}\text { Higher } \\
\text { Wyższe }\end{array}$ & 29 & 24 \\
\hline
\end{tabular}

$* \mathrm{OG}-$ obese group, $* * \mathrm{RG}-$ reference group.

*GO - grupa otyłych, **GK - grupa kontrolna.

\section{Results}

Respondents were asked to define the frequency of undertaking preferred eating behaviors (Table 2). The study considered mainly the frequency of meals consumption. $59 \%$ of the obese group and $44 \%$ from the reference group did not eat breakfast. About $20 \%$ of respondents from both groups had breakfast everyday or several times a week.

Another question concerned main meals consumed by the respondents. For $64 \%$ of obese respondents and $68 \%$ in the reference group dinner was the most important everyday meal. For the assessment of health-promoting behaviors the quantity and regularity of meals seemed significant as well. More than half of respondents $(63 \%$ obese and $66 \%$ of the reference group) claimed that they consumed 4-5 meals everyday or several times a week. Obese people significantly more often marked the daily observance of this principle when compared to those with a normal BMI. 
Jędrusek-Golińska, A., Szymandera-Buszka, K., Magott, M. (2016). Comparison of the level of nutritional knowledge and selected behaviour among consumers with regular BMI and the obese. Nauka Przyr. Technol., 10, 4, \#57. DOI: http://dx.doi.org/10.17306/J.NPT.2016.4.57

Table 2. Selected nutritional behaviors of respondents

Tabela 2. Wybrane zachowania żywieniowe respondentów

\begin{tabular}{|c|c|c|c|c|c|c|}
\hline \multirow[b]{2}{*}{$\begin{array}{l}\text { Behavior } \\
\text { Zachowanie }\end{array}$} & \multirow[b]{2}{*}{$\begin{array}{l}\text { Group } \\
\text { Grupa }\end{array}$} & \multicolumn{4}{|c|}{$\begin{array}{c}\text { Declared frequency of behavior }(\%) \\
\text { Deklarowana częstość zachowania (\%) }\end{array}$} & \multirow[b]{2}{*}{$\mathrm{P} * * *$} \\
\hline & & $\begin{array}{l}\text { everyday } \\
\text { codziennie }\end{array}$ & $\begin{array}{l}\text { a few times } \\
\text { a week } \\
\text { kilka razy } \\
\text { w tygodniu }\end{array}$ & $\begin{array}{l}\text { kilka razy w } \\
\text { miesiącu } \\
\text { a few times } \\
\text { a month }\end{array}$ & $\begin{array}{l}\text { never } \\
\text { nigdy }\end{array}$ & \\
\hline \multirow{2}{*}{$\begin{array}{l}\text { I eat breakfast } \\
\text { Jem śniadanie }\end{array}$} & $\mathrm{OG}^{*}$ & 13 & 7 & 21 & 59 & 0.06 \\
\hline & $\mathrm{RG}^{* *}$ & 6 & 14 & 36 & 44 & \\
\hline \multirow{2}{*}{$\begin{array}{l}\text { My main meal is breakfast } \\
\text { Moim głównym posiłkiem jest } \\
\text { śniadanie }\end{array}$} & OG & 10 & 11 & 17 & 62 & 0.65 \\
\hline & RG & 5 & 16 & 31 & 48 & \\
\hline \multirow{2}{*}{$\begin{array}{l}\text { My main meal is midday meal } \\
\text { Moim głównym posiłkiem jest } \\
\text { obiad }\end{array}$} & OG & 64 & 20 & 8 & 8 & 0.44 \\
\hline & RG & 68 & 18 & 14 & 0 & \\
\hline \multirow{2}{*}{$\begin{array}{l}\text { My main meal is dinner } \\
\text { Moim głównym posiłkiem jest } \\
\text { obiadokolacja }\end{array}$} & OG & 14 & 18 & 24 & 44 & 0.29 \\
\hline & RG & 6 & 12 & 26 & 56 & \\
\hline \multirow{2}{*}{$\begin{array}{l}\text { I eat } 4-5 \text { meals a day } \\
\text { Spożywam } 4-5 \text { posiłków dziennie }\end{array}$} & OG & 46 & 17 & 24 & 13 & 0.00 \\
\hline & RG & 18 & 48 & 16 & 18 & \\
\hline \multirow{2}{*}{$\begin{array}{l}\text { I eat meals prepared at home } \\
\text { Jem posiłki przygotowane w domu }\end{array}$} & OG & 65 & 28 & 5 & 2 & 0.06 \\
\hline & $\mathrm{RG}$ & 52 & 30 & 18 & 0 & \\
\hline
\end{tabular}

*OG - obese group, ${ }^{* *} \mathrm{RG}-$ reference group, $* * * \mathrm{p}-\mathrm{Chi}^{2}$.

$* \mathrm{GO}$ - grupa otyłych, $* * \mathrm{GK}-$ grupa kontrolna, $* * * \mathrm{p}-\mathrm{Chi}^{2}$.

The care given to the quality of the food supplied to the body is linked by some (Bezerra et al., 2012) with the preparation of meals at home. Therefore, respondents also answered the question how often they eat meals prepared by themselves or a member of the family. The majority of respondents $(65 \%$ and $52 \%)$ declared that they did it every day; only $2 \%$ of obese respondents ate out exclusively.

The questionnaire included claims about the effects of certain food ingredients on the health and general condition of the body (Table 3). In four of the six statements about dietary fiber (T1, T2, T4 and T6), the frequency of correct answers was higher among obese people than in the reference group. Significantly more respondents with normal BMI (0.6 vs. 0.38) knew that dietary fiber helps lower blood cholesterol (T5). Knowledge of obese respondents concerning fiber was on high level $(0,71-1,0)$, with the exception of claim 5. Obese respondents showed a significantly higher average level of knowledge of dietary fiber than people with normal weight. The level of respondents' knowledge of the role of calcium in the body and products that may be its source in the diet was mainly on a high level (T7, T8 in both groups). The BMI index value did not affect the level of respondents' knowledge. 
Jędrusek-Golińska, A., Szymandera-Buszka, K., Magott, M. (2016). Comparison of the level of nutritional knowledge and selected behaviour among consumers with regular BMI and the obese. Nauka Przyr. Technol., 10, 4, \#57. DOI: http://dx.doi.org/10.17306/J.NPT.2016.4.57

Table 3. Level of respondents' nutritional knowledge

Tabela 3. Poziom wiedzy żywieniowej respondentów

\begin{tabular}{|c|c|c|c|c|}
\hline $\mathrm{T}$ & Claim content - Treść twierdzenia & $\begin{array}{l}\mathrm{OG}^{*} \\
\mathrm{GO}^{*}\end{array}$ & $\begin{array}{l}\mathrm{RG}^{* *} \\
\mathrm{GK}^{* *}\end{array}$ & $\mathrm{P} * * *$ \\
\hline 1 & 2 & 3 & 4 & 5 \\
\hline \multicolumn{5}{|c|}{$\begin{array}{l}\text { The level of knowledge of the role and sources of fiber } \\
\text { Poziom wiedzy o roli i źródłach błonnika }\end{array}$} \\
\hline $\mathrm{T} 1$ & $\begin{array}{l}\text { Graham bread is a good source of dietary fiber } \\
\text { Chleb graham jest dobrym źródłem błonnika }\end{array}$ & 0.82 & 0.32 & 0.00 \\
\hline $\mathrm{T} 2$ & $\begin{array}{l}\text { Fruits and vegetables are a good source of dietary fiber } \\
\text { Owoce i warzywa są dobrym źródłem błonnika }\end{array}$ & 0.76 & 0.52 & 0.01 \\
\hline $\mathrm{T} 3$ & $\begin{array}{l}\text { Wheat bread contains more fiber than wholemeal bread } \\
\text { Chleb pszenny jasny zawiera więcej błonnika niż chleb razowy }\end{array}$ & 0.73 & 0.66 & 0.54 \\
\hline $\mathrm{T} 4$ & $\begin{array}{l}\text { Presence of dietary fiber has a positive effect on the digestive system } \\
\text { Obecność błonnika wpływa pozytywnie na układ pokarmowy }\end{array}$ & 0.81 & 0.61 & 0.02 \\
\hline T5 & $\begin{array}{l}\text { Dietary fiber promotes lowering cholesterol in blood } \\
\text { Błonnik pokarmowy sprzyja obniżeniu poziomu cholesterolu we krwi }\end{array}$ & 0.38 & 0.6 & 0.03 \\
\hline T6 & $\begin{array}{l}\text { Dietary fiber prevents obstruction } \\
\text { Błonnik pokarmowy zapobiega zaparciom }\end{array}$ & 0.72 & 0.36 & 0.00 \\
\hline T1-T6 & $\begin{array}{l}\text { Average knowledge level about the role and sources of fiber } \\
\text { Średni poziom wiedzy o roli i źródłach błonnika }\end{array}$ & 0.70 & 0.51 & 0.02 \\
\hline \multicolumn{5}{|c|}{$\begin{array}{l}\text { The level of knowledge about the role and sources of calcium } \\
\text { Poziom wiedzy o roli i źródłach wapnia }\end{array}$} \\
\hline $\mathrm{T} 7$ & $\begin{array}{l}\text { Fish is a good source of calcium in the diet } \\
\text { Ryby są dobrym źródłem wapnia w diecie }\end{array}$ & 0.56 & 0.54 & 0.88 \\
\hline $\mathrm{T} 8$ & $\begin{array}{l}\text { Cheese is a good source of calcium in the diet } \\
\text { Ser żółty jest dobrym źródłem wapnia w diecie }\end{array}$ & 0.54 & 0.57 & 0.18 \\
\hline T9 & $\begin{array}{l}\text { Fruits are a good source of calcium in the diet } \\
\text { Owoce są dobrym źródłem wapnia w diecie }\end{array}$ & 0.34 & 0.38 & 0.36 \\
\hline $\mathrm{T} 10$ & $\begin{array}{l}\text { Sufficient calcium intake ensures proper bone mineralization } \\
\text { Wystarczająca podaż wapnia zapewnia odpowiednią mineralizację kości }\end{array}$ & 0.73 & 0.43 & 0.73 \\
\hline $\begin{array}{l}\mathrm{T} 7- \\
-\mathrm{T} 10\end{array}$ & $\begin{array}{l}\text { Average knowledge level about the role and sources of calcium } \\
\text { Sredni poziom wiedzy o roli i źródłach wapnia }\end{array}$ & 0.54 & 0.48 & 0.49 \\
\hline \multicolumn{5}{|c|}{$\begin{array}{l}\text { The level of knowledge about the role and sources of n-3 and n-6 fatty acids } \\
\text { Poziom wiedzy o roli i źródłach kwasów n-3 i n-6 }\end{array}$} \\
\hline T11 & $\begin{array}{l}\text { n-3 and n-6 fatty acids prevent cardiovascular diseases } \\
\text { Kwasy n-3 i n-6 przeciwdziałają chorobom krążenia }\end{array}$ & 0.63 & 0.46 & 0.03 \\
\hline $\mathrm{T} 12$ & $\begin{array}{l}\text { Butter is a good source of n-3 and n- } 6 \text { fatty acids } \\
\text { Masło jest dobrym źródłem kwasów n-3 i n-6 }\end{array}$ & 0.32 & 0.32 & 0.73 \\
\hline $\mathrm{T} 13$ & $\begin{array}{l}\text { n-3 and n-6 fatty acids ensure normal development of the nervous system } \\
\text { Kwasy n-3 i n-6 zapewniają prawidłowy rozwój układu nerwowego }\end{array}$ & 0.47 & 0.32 & 0.47 \\
\hline
\end{tabular}


Jędrusek-Golińska, A., Szymandera-Buszka, K., Magott, M. (2016). Comparison of the level of nutritional knowledge and selected behaviour among consumers with regular BMI and the obese. Nauka Przyr. Technol., 10, 4, \#57. DOI: http://dx.doi.org/10.17306/J.NPT.2016.4.57

Table 3 - cont. / Tabela 3 - cd.

\begin{tabular}{|c|c|c|c|c|}
\hline 1 & 2 & 3 & 4 & 5 \\
\hline $\begin{array}{l}\mathrm{T} 11- \\
-\mathrm{T} 13\end{array}$ & $\begin{array}{l}\text { Average knowledge level about the role and sources of n-3 and n-6 fatty } \\
\text { acids } \\
\text { Średni poziom wiedzy o roli i źródłach kwasów n-3 i n-6 }\end{array}$ & 0.47 & 0.37 & 0.19 \\
\hline \multicolumn{5}{|c|}{$\begin{array}{l}\text { The level of knowledge about the role and sources of probiotics } \\
\text { Poziom wiedzy o roli i źródłach probiotyków }\end{array}$} \\
\hline $\mathrm{T} 14$ & $\begin{array}{l}\text { Probiotics help increase immunity and the growth of normal intestinal } \\
\text { flora } \\
\text { Probiotyki sprzyjają podnoszeniu odporności i rozwojowi prawidłowej } \\
\text { mikroflory przewodu pokarmowego }\end{array}$ & 0.63 & 0.38 & 0.00 \\
\hline $\mathrm{T} 15$ & $\begin{array}{l}\text { Probiotics are a selected culture of bacteria and yeasts } \\
\text { Probiotyki to wyselekcjonowane kultury bakterii i drożdży }\end{array}$ & 0.56 & 0.38 & 0.09 \\
\hline $\begin{array}{l}\mathrm{T} 14- \\
-\mathrm{T} 15\end{array}$ & $\begin{array}{l}\text { Average knowledge level about the role and sources of probiotics } \\
\text { Średni poziom wiedzy o roli i źródłach probiotyków }\end{array}$ & 0.59 & 0.38 & 0.10 \\
\hline \multicolumn{5}{|c|}{$\begin{array}{l}\text { The level of knowledge about the role and sources of bioactive substances } \\
\text { Poziom wiedzy o roli i źródłach składników bioaktywnych }\end{array}$} \\
\hline T16 & $\begin{array}{l}\text { Fruits and vegetables contain natural antioxidants that protect the body } \\
\text { against free radicals } \\
\text { Owoce i warzywa zawierają naturalne przeciwutleniacze chroniące or- } \\
\text { ganizm przed wolnymi rodnikami }\end{array}$ & 0.72 & 0.6 & 0.111 \\
\hline $\mathrm{T} 17$ & $\begin{array}{l}\text { Coffee contains bioactive components } \\
\text { Kawa zawiera składniki bioaktywne }\end{array}$ & 0.17 & 0.2 & 0.88 \\
\hline $\mathrm{T} 18$ & $\begin{array}{l}\text { Bioactive components are used to preserve food } \\
\text { Składniki bioaktywne są używane do konserwowania żywności }\end{array}$ & 0.44 & 0.38 & 0.24 \\
\hline $\begin{array}{l}\text { T16- } \\
-\mathrm{T} 18\end{array}$ & $\begin{array}{l}\text { Average knowledge level about the role and sources of bioactive sub- } \\
\text { stances } \\
\text { Średni poziom wiedzy o roli i źródłach składników bioaktywnych }\end{array}$ & 0.44 & 0.39 & 0.37 \\
\hline \multicolumn{2}{|c|}{$\begin{array}{l}\text { The knowledge (T1-T18) } \\
\text { Poziom wiedzy (T1-T18) }\end{array}$} & 0.58 & 0.43 & 0.01 \\
\hline
\end{tabular}

*OG - obese group, **RG - reference group, ***P-Chi ${ }^{2}$ for $\mathrm{T} 1-\mathrm{T} 19$ and for average knowledge level, t-test.

*GO - grupa otyłych, **GK - grupa kontrolna, ***p-Chi² dla T1-T19 i dla średniego poziomu wiedzy, test t.

Lower scores were obtained for claims related to n-3 and -6 fatty acids. Respondents from both groups well assessed the truth of claim (T11), speaking about the role of these fatty acids in the prevention of cardiovascular diseases; the level of their knowledge on the subject depended on the value of BMI. Other claims (T12 and T13) showed respondents' lower understanding of the sources of n-3 and -6 acids in the diet and their impact on the development of the nervous system. In the case of statements regarding probiotics (T14-15), the level of respondents' knowledge from both groups differed significantly as to the role of these bacteria in the increase of immunity and development of good microflora of the gastrointestinal tract. Numerous respondents in both 
Jędrusek-Golińska, A., Szymandera-Buszka, K., Magott, M. (2016). Comparison of the level of nutritional knowledge and selected behaviour among consumers with regular BMI and the obese. Nauka Przyr. Technol., 10, 4, \#57. DOI: http://dx.doi.org/10.17306/J.NPT.2016.4.57

groups knew that fruits and vegetables contain natural antioxidants, protecting the organism against free radicals (T16). Very few of all respondents knew that coffee contains bioactive components (T17) - both groups showed a low level of knowledge on this subject. The key here might be the phrase "bioactive components" because, as shown by the opinions on the following statement (T18), the majority of the respondents either does not know what they are or associates them with e.g. preservatives. The value of the body mass index had no effect on the level of respondents' knowledge about bioactive components.

The analysis of responses using the t-test revealed that although the average level of knowledge of the respondents in both groups on the individual food components differ significantly only in certain cases, the general level of knowledge of all the ingredients together was significantly higher in obese respondents.

\section{Discussion}

Proper nutrition, in addition to a proper balance of nutrients, should provide a permanent structure of meals, maintenance of proper regularity and frequency of consumption. Daily breakfast consumption and not overeating for dinner (Tsigos et al., 2008) are believed to be essential.

In the research presented over $60 \%$ of respondents from both groups consumed 4-5 meals every day or several times a week. This is a result similar to that obtained by Ostrowska et al. (2002), but higher than those described in the studies of Szczepańska et al. (2013), where such a declaration was made by approximately $40 \%$ of patients with higher and primary education and $25 \%$ with a secondary education degree.

The impact of not eating breakfast on obesity is widely discussed (Dhurandhar et al., 2014). There are results suggesting that eating breakfast, especially a high-protein one, causes a decrease in appetite for sweet, salty and greasy foods (Leidy and Racki, 2010). This can be explained, among others, by higher levels of dopamine in the blood, which is a neurotransmitter from the group of catecholamines and is responsible for the interpretation of emotional stimuli (Drożdżak and Bryła, 2005). On the other hand, Brown et al. (2013), conducted a detailed analysis of data from the world literature, and claim that even though the belief about the impact of not eating breakfast on the development of obesity is at a level of over $80 \%$, scientific evidence can only confirm it in about $20 \%$. Everyday consumption of breakfast is associated with a higher activity of postprandial thermogenesis in slim persons, but impact of this eating behavior on the height of the resting metabolic rate has not been proven. It has been demonstrated, however, that eating breakfast (in contrast to fasting) is associated with more stable blood glucose in the afternoon and evening (Betts et al., 2014).

One of the crucial issues in the development of obesity appears to be the increase of the size of consumed portions, as a result of overeating seizures, especially without the subsequent reduction in energy consumption. Great importance is attributed to the hour at which meals are consumed (Ostrowska, 2010). In addition to the necessity of eating the last meal no later than 2-3 hours before bedtime, it also raises the question of reducing the number of calories provided with lunch or dinner (Jakubowicz et al., 2013). It is 
Jędrusek-Golińska, A., Szymandera-Buszka, K., Magott, M. (2016). Comparison of the level of nutritional knowledge and selected behaviour among consumers with regular BMI and the obese. Nauka Przyr. Technol., 10, 4, \#57. DOI: http://dx.doi.org/10.17306/J.NPT.2016.4.57

believed (Ostrowska, 2010) that the maintenance of a healthy body weight is associated with a hygienic life-style, care given to the quality of food and sufficient food intake, but also with nutritional knowledge. Obese respondents were more familiarized with information regarding dietary fiber. Similarly, in the study of Thakur and D'Amico (1999), obese respondents better identified the foods with a higher content of dietary fiber. That knowledge is deemed essential, because a diet rich in products that are a good source of dietary fiber promotes a weight loss; data obtained with the use of fiber supplements do not seem to be so clear (Papathanasopoulos and Camilleri, 2010). The respondents' knowledge of calcium and polyunsaturated fatty acids of family n-3 and n-6 was varied. Supplementation of diet with n-3 acids could - by reducing plasma triglyceride levels - alleviate insulin resistance, hypertension, and dyslipidemia, in the course of obesity-related metabolic syndrome (Lorente-Cebrián et al., 2013). On the other hand, an adequate intake of antioxidants naturally present in food can reduce oxidative damage associated with obesity, dangerous especially in co-existing hyperglycemia and hyperlipidemia (Erdeve et al., 2004).

A link between knowledge and eating behaviors were studied by Thakur and D'Amico (1999), who found no differences in the level of general knowledge concerning the principles of nutrition between obese and lean respondents. What is more important, a number of publications show that often, despite sufficient nutritional knowledge, eating habits remain unsatisfactory, both among adults and adolescents (Wojtyła-Buciora and Marcinkowski, 2010).

Nevertheless, it appears that the education of adults and children as well as whole families is one of the right ways to control the epidemic of obesity. It is important to transfer the knowledge in an easy-to-remember way, to implement it, and to encourage a change in eating habits.

\section{Conclusions}

1. Comparison of dietary behaviors of respondents with normal weight and obese indicates that in both groups the most common mistake was not eating breakfast. Due to the importance of this meal in the daily diet, this habit should be changed.

2 . The level of nutritional knowledge of the respondents in both groups was at a medium level. Obese respondents showed a significantly higher level of knowledge concerning selected food ingredients.

3. It appears that further, effective nutritional education is a necessary element helping contain the epidemic of obesity. It should include not only promotion of nutritional knowledge, but also the motivation to change current improper habits.

\section{References}

Betts, J., Richardson, J. D., Chowdhury, E., Holman, G. D., Tsintzas, K., Thompson, D. (2014). The causal role of breakfast in energy balance and health: A randomized controlled trial in lean adults. Am. J. Clin. Nutr., 100, 2, 539-547. DOI: 10.3945/ajcn.114.083402 
Jędrusek-Golińska, A., Szymandera-Buszka, K., Magott, M. (2016). Comparison of the level of nutritional knowledge and selected behaviour among consumers with regular BMI and the obese. Nauka Przyr. Technol., 10, 4, \#57. DOI: http://dx.doi.org/10.17306/J.NPT.2016.4.57

Bezerra, I. N., Curioni, C., Sichieri, R. (2012). Association between eating out of home and body weight. Nutr. Rev., 70, 2, 65-79. DOI: 10.1111/j.1753-4887.2011.00459.x

Brown, A. W., Bohan Brown, M. M., Allison, D. B. (2013). Belief beyond the evidence: using the proposed effect of breakfast on obesity to show 2 practices that distort scientific evidence 1-4. Am. J. Clin. Nutr., 98, 5, 1298-1308. DOI: 10.3945/ajen.113.064410

Drożdżak, J., Bryła, J. (2005). Dopamina - nie tylko neuroprzekaźnik. Post. Hig. Med. Dośw., 59, 405-420.

Dhurandhar, E. J., Dawson, J., Alcorn, A., Larsen, L. H., Thomas, E. A., Cardel, M., Bourland, A. C., Astrup, A., St-Onge, M.-P., Hill, J. O., Apovian, C. M., Shikany, J. M., Allison, D. B. (2014). The effectiveness of breakfast recommendations on weight loss: a randomized controlled trial. Am. J. Clin. Nutr., 100, 2, 507-513. DOI: 10.3945/ajcn.114.089573

Erdeve, O., Siklar, Z., Kocaturk, P. A., Dallar, Y., Kavas, G. O. (2004). Antioxidant superoxide dismutase activity in obese children. Biol. Trace Elem. Res., 98, 219-227. DOI: 10.1385/ BTER:98:3:219

Jakubowicz, D., Barnea, M., Wainstein, J., Froy, O. (2013). High caloric intake at breakfast vs. dinner differentially influences weight loss of overweight and obese women. Obesity (Silver Spring), 21, 12, 2504-2512. DOI: 10.1002/oby.20460

Leidy, H. J., Racki, E. M. (2010). The addition of a protein-rich breakfast and its effects on acute appetite control and food intake in 'breakfast-skipping' adolescents. (2010). Int. J. Obes., 34, 7, 1125-1133. DOI: 10.1038/ijo.2010.3

Lorente-Cebrián, S., Costa, A. G. V., Navas-Carretero, S., Zabala, M., Martínez, J. A., Moreno-Aliaga, M. J. (2013). Role of omega-3 fatty acids in obesity, metabolic syndrome, and cardiovascular diseases: a review of the evidence. J. Physiol. Biochem., 69, 3, 633-651. DOI: 10.1007/s13105-013-0265-4

Ostrowska, L., Czapska, D., Karczewski, J., Krzemińska, A. (2002) Zachowania żywieniowe osób z nadwagą i otyłością. Bromat. Chem. Toksykol., 35, 2, 139-146.

Ostrowska, L. (2010). Leczenie dietetyczne otyłości - wskazówki dla lekarzy praktyków. Forum Zaburzeń Metabol., 1, 1, 22-30.

Papathanasopoulos, A., Camilleri, M. (2010). Dietary fiber supplements: effects in obesity and metabolic syndrome and relationship to gastrointestinal functions. Gastroenterol., 138, 1, 6572. DOI: $10.1053 /$ j.gastro.2009.11.045

Szczepańska, E., Brończyk-Puzoń, A., Skrzypek, M. (2013). Wiedza a wybrane zachowania żywieniowe pacjentów z otyłością w zależności od poziomu ich wykształcenia. Probl. Hig. Epidemiol. 94, 4, 802-806.

Thakur, N., D'Amico, F. (1999). Relationship of nutrition knowledge and obesity in adolescence. Fam. Med., 31, 2, 122-127.

Tsigos, C., Hainer, V., Basdevant, A. (2008). Management of obesity in adults. European clinical practice guidelines. Obes. Facts, 1, 106-116. DOI: 10.1159/000126822

Wojtyła-Buciora, P., Marcinkowski, J. T. (2010). Sposób żywienia, zadowolenie z własnego wyglądu i wyobrażenie o idealnej sylwetce młodzieży licealnej. Probl. Hig. Epidemiol., 91, 2, 227-232.

WHO (2015). European Food and Nutrition Action Plan 2015-2020, http://www.euro.who.int/ data/assets/pdf_file/0003/294474/European-Food-Nutrition-Action-Plan-20152020en.pdf?ua $=1$. 
Jędrusek-Golińska, A., Szymandera-Buszka, K., Magott, M. (2016). Comparison of the level of nutritional knowledge and selected behaviour among consumers with regular BMI and the obese. Nauka Przyr. Technol., 10, 4, \#57. DOI: http://dx.doi.org/10.17306/J.NPT.2016.4.57

\title{
PORÓWNANIE POZIOMU WIEDZY ŻYWIENIOWEJ I WYBRANYCH ZACHOWAŃ U KONSUMENTÓW NORMOWAGOWYCH I OTYŁYCH
}

\begin{abstract}
Streszczenie
Wstęp. Ze względu na narastającą epidemię otyłości konieczne jest podejmowanie działań mających zahamować jej rozwój. Aby próbować wprowadzić pożądane zmiany w diecie osób otyłych, trzeba najpierw dobrze poznać ich zachowania żywieniowe oraz wiedzę na temat składników odżywczych i ich roli.

Material i metody. Metodą wywiadu bezpośredniego badano osoby z podwyższonym $(\mathrm{n}=100)$ i prawidłowym BMI $(n=100)$ z Wielkopolski. Celem badania było porównanie wybranych zachowań związanych $\mathrm{z}$ odżywianiem oraz poziomu wiedzy osób z podwyższonym i prawidłowym wskaźnikiem masy ciała.

Wyniki. Nigdy nie jadało śniadań 59\% osób z grupy otyłych oraz $44 \%$ z grupy referencyjnej. Dla $64 \%$ otyłych respondentów i $68 \%$ z grupy kontrolnej głównym posiłkiem w ciągu dnia był obiad. Ponad połowa respondentów (63\% otyłych i $66 \%$ z grupy kontrolnej) twierdziła, że codziennie lub kilka razy w tygodniu spożywa 4-5 posiłków. Otyli ankietowani wykazali się dużym zasobem wiedzy na temat błonnika pokarmowego oraz naturalnych źródeł przeciwutleniaczy w żywności. Wykazano, że ogólny poziom wiedzy respondentów na temat składników żywności był średni.

Wnioski. Koniecznym elementem opanowania epidemii otyłości jest dalsza, skuteczna edukacja żywieniowa. Powinna ona obejmować nie tylko szerzenie wiedzy żywieniowej, ale także motywowanie do zmiany dotychczasowych nieprawidłowych nawyków.
\end{abstract}

Slowa kluczowe: wiedza żywieniowa, zachowania żywieniowe, otyłość

Corresponding address - Adres do korespondencji:

Anna Jędrusek-Golińska, Katedra Technologii Żywienia Człowieka, Uniwersytet Przyrodniczy w Poznaniu, ul. Wojska Polskiego 28, 60-637 Poznań, Poland, e-mail: angol@up.poznan.pl

Accepted for publication - Zaakceptowano do opublikowania:

19.12.2016

For citation - Do cytowania:

Jędrusek-Golińska, A., Szymandera-Buszka, K., Magott, M. (2016). Comparison of the level of nutritional knowledge and selected behaviour among consumers with regular BMI and the obese. Nauka Przyr. Technol., 10, 4, \#57. DOI: http://dx.doi.org/10.17306/J.NPT.2016.4.57 